\title{
INFLUENCE OF ACOUSTIC FREQUENCY ON BEAN GERMINATION AND GROWTH PROCESS
}

\author{
ALISA MOȘNEAGA*1, VALENTIN NEDEFF ${ }^{2}$, PETRU LOZOVANU ${ }^{1}$ \\ ${ }^{1}$ State University of Moldova, Laboratory of Environment Metrology and Astronomy, 60 \\ Mateevici Str., Chisinau, MD-2009, Moldova \\ 2 “Vasile Alecsandri” University of Bacau, 157, Calea Marasesti, Bacau, 600115, Romania
}

\begin{abstract}
In this work, research findings on processing bean seeds with sound waves in the range $0-9 \mathrm{kHz}$ are presented. The process of germination has been examined for seeds soaked in heat treated water and plain water. In the initial stage, the conditions necessary to stimulate plant growth were created. The paper describes the experimental setup and the sound wave seed treatment procedure. The characteristics of the seed germination process were determined and compared with those of the control sample germination.
\end{abstract}

Keywords: sound wave, agricultural culture, mechanical oscillations, growth stimulation, ecological treatment

\section{INTRODUCTION}

Agriculture, as an important branch of economy, has to solve one of the major global problems of humanity, namely food security and environmental protection - a problem that has greatly worsened in recent years [1-3]. To find solutions and to establish a relationship of balance between nature and society, recent approaches to agricultural production aim to reduce and reverse environmental degradation processes [2]. In this context, it is of interest to create new methods of organic and no stressful treatment of agricultural cultures in all stages of development, in order to reduce the period of germination and enhance the immune system of plants. As an alternative to chemical stimulation methods in plant growth, the modulation of physical fields would help to avoid the pollution of food raw materials with toxic substances [4-6].

\section{EXPERIMENTAL SETUP}

The veracity of the results obtained from experiments made on agricultural cultures largely depends on the selection of the samples for testing. Beans of the Pink variety (Phaseolus vulgaris) were chosen for the present study. Initially, the seeds were thermostated at $10{ }^{\circ} \mathrm{C}$ up to a relative humidity of $10 \%$. For research purposes, seeds of regular shape, characteristic of the variety and weighing $0,001 \mathrm{~g}$ mass within $\pm 2 \%$ deviation were selected. For treating the seeds with sound waves, a setup has been designed, produced and used, as shown in Figure 1.

On a fixed support 1 , a cylinder 2 is installed, the inner surface of which is covered with a sound wave absorbent layer 3. The seeds are put on the support 4, which is a movable metal grille that can be fixed in a certain position with the screw 5 . The surface is coated with a porous material 6 , which allows good air circulation in the

\footnotetext{
*Corresponding author, email: alisa.mosneaga@ mail.ru

(C) 2016 Alma Mater Publishing House
} 
cylinder. All seeds 7 subjected to treatment are put on the carrier in the same position, which cannot be changed during the process of the treatment. On top of the cylinder, a speaker 8 is set and connected to the sound generator 9 .

The specifics of the installation consist in forming a flow of sound waves oriented towards the seeds, avoiding the occurrence of reflection and resonance phenomena.

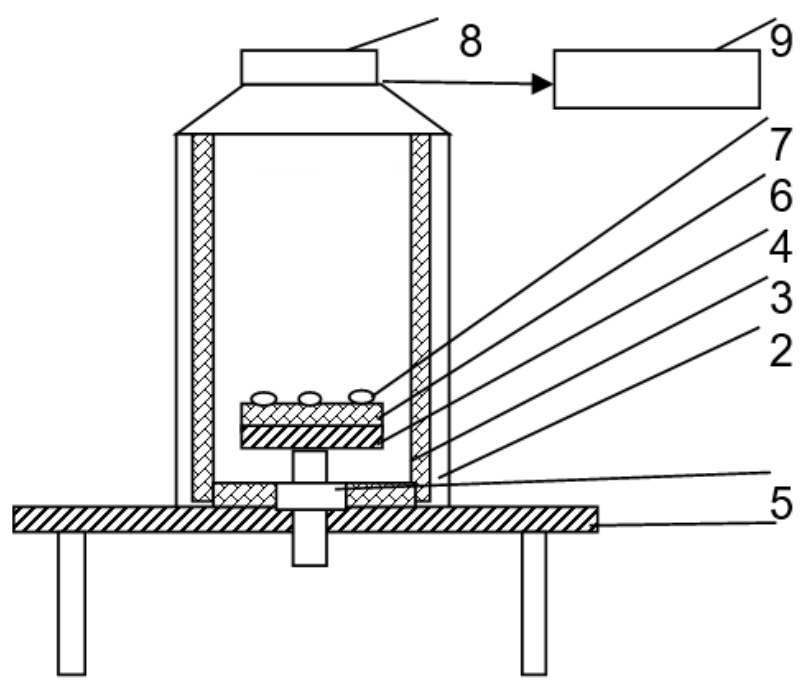

Fig. 1. The setup for acoustic frequency treatment of seeds:

1- fixed stand, 2 - cylinder, 3- absorbent layer , 4 - mobile support, 5 - screw, 6 - porous material, 7 - seeds used for treatment, 8 - diffuser, 9- sound generator.

9 seeds were selected for the treatment. Initially, a certain direction was determined for the seeds , then they were positioned on the surface of the mobile support 5 and subjected to the action of sound waves of a certain frequency for 5 minutes each, on both sides. Further, the seeds were placed in separate cells, so that the seed axis direction was oriented to the north and were immersed into water. For the tests, plain water with known parameters and water subjected to heat treatment was used. For the purpose of the heat treatment, the water was kept in the freezer for $24 \mathrm{~h}$ and then thawed. Seed treatment was performed for 5 days; seed weight was determined relative to the initial mass at specific time intervals. During the treatment, measurements were made within $24 \mathrm{~h}$, and the ranges where deviations appear from the characteristic dependence, measurements were performed in the range of 4 hours. The measurement was performed using a handling system that allowed moving the seed without changing its position in space. This method was carried out for not changing the position of the seeds in relation to the direction the magnetic field of the earth. The seed treatment was carried out under conditions of minimal fluctuation of the magnetic and electric fields and of background sound waves.

After germination, the seeds were planted in soil under laboratory conditions. Planting was carried out in such a way as to maintain the orientation of the beans, as well as the treatment phase with sound waves. Growth conditions were maintained within the temperature limits of $25 \pm 1{ }^{\circ} \mathrm{C}$ and humidity of $65 \pm 3 \%$. For the exact determination of the strain height, an optical-mechanical cathetometer type KM- 8 was used. The diameter of the plant stems was measured by a microscopic system for determining the horizontal linear dimensions, calibrated to an accuracy of $0.001 \mathrm{~mm}$.

\section{RESULTS AND DISCUSSION}

\subsection{Influence of sound waves on the germination process}

A key feature of living organisms is the ability to react and respond to different physical incentives. Analyzing the results, we find that there is no parallelism between water absorption and the nature of the physical factor, each having specific laws of penetrating the bean seeds. The figures below present the dependence of seed mass change on treatment time for the seeds treated with different frequencies and soaked in plain water and heat- 
treated water. For estimating the biological activity of the seeds, the mass increase was assessed according to the relation:

$$
\delta=\Delta \mathrm{m}_{\mathrm{i}} / \mathrm{m}_{\mathrm{i}}
$$

where $\Delta \mathrm{m}_{\mathrm{i}}$ represents the difference between the mass obtained at the time of measurement $\mathrm{m}_{\mathrm{i}}$ and the weight value $\mathrm{m}_{\mathrm{i}-1}$ of the previous one.

$$
\Delta \mathrm{m}_{\mathrm{i}}=\mathrm{m}_{\mathrm{i}-1}-\mathrm{m}_{\mathrm{i}}
$$

Figure 2 illustrates the dependence of $\delta=\mathrm{f}(\mathrm{t})$ for the seeds soaked in plain water and in heat-treated water. The figure shows that the seed mass increased the most after the first 24 hours of soaking the seeds in water. Depending on the frequency, the mass of the treated seeds showed a different evolution as compared to that of the control sample.

The maximum difference was observed for the samples treated at a frequency of $1 \mathrm{kHz}$. After 48 hours of treatment, the mass increase was reduced for both plain water and treated water, in the most cases, $\delta$ is close to 0 , except for the changes observe the frequencies of $1 \mathrm{kHz}$ and $7 \mathrm{kHz}$.

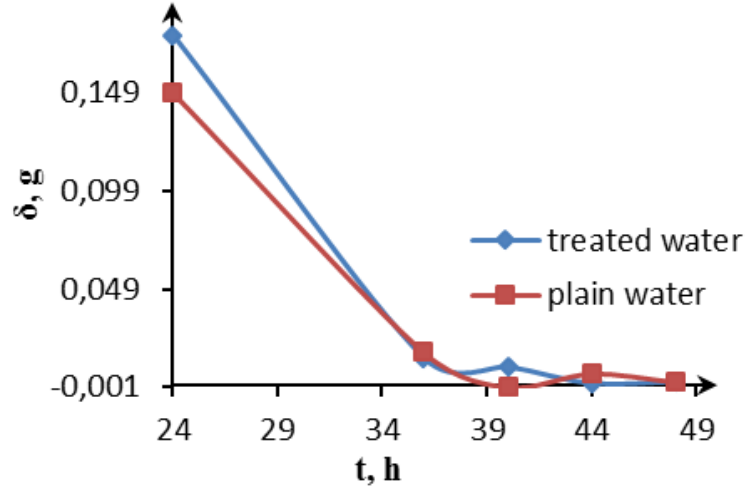

a

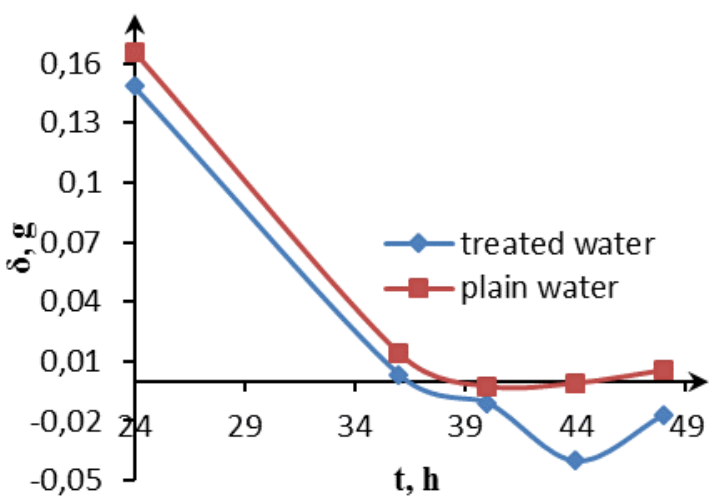

b

Fig. 2. The dependence of mass variation as a function of time for the seeds: a- control sample, $\mathrm{b}$ - sample treated with $0.5 \mathrm{kHz}$ frequency sound

These parameters were determined similarly for acoustic frequencies of $0-9 \mathrm{kHz}$ (Table 1 ).

\begin{tabular}{|c|c|c|c|c|c|c|c|c|}
\hline \multirow[t]{2}{*}{ Time, $\mathrm{h}$} & \multicolumn{2}{|c|}{ mass, $\mathrm{g}$} & \multicolumn{2}{|c|}{$\Delta \mathrm{m}, \mathrm{g}$} & \multicolumn{2}{|c|}{$\delta, \mathrm{g}$} & \multicolumn{2}{|c|}{$\begin{array}{c}\text { Time of } \\
\text { germination }\end{array}$} \\
\hline & $\begin{array}{l}\text { Plain } \\
\text { water }\end{array}$ & $\begin{array}{l}\text { Treated } \\
\text { water }\end{array}$ & $\begin{array}{l}\text { Plain } \\
\text { water }\end{array}$ & $\begin{array}{l}\text { Treated } \\
\text { water }\end{array}$ & $\begin{array}{l}\text { Plain } \\
\text { water }\end{array}$ & $\begin{array}{c}\text { Treated } \\
\text { water }\end{array}$ & $\begin{array}{l}\text { Plain } \\
\text { water }\end{array}$ & $\begin{array}{c}\text { Treated } \\
\text { water }\end{array}$ \\
\hline \multicolumn{9}{|c|}{ Control sample } \\
\hline 0 & 0,557 & 0,602 & - & - & - & - & & \\
\hline 24 & 1,114 & 1,301 & 0.557 & 0.699 & 0.14897 & 0.178044 & & \\
\hline 36 & 1,178 & 1,355 & 0.064 & 0.054 & 0.016829 & 0.013568 & & \\
\hline 40 & 1,175 & 1,392 & -0.003 & 0.037 & -0.00079 & 0.009211 & & \\
\hline 44 & 1,198 & 1,395 & 0.023 & 0.003 & 0.006016 & 0.000746 & & + \\
\hline 48 & 1,205 & 1,398 & 0.007 & 0.006 & 0.001828 & 0.001491 & + & \\
\hline \multicolumn{9}{|c|}{$3 \mathrm{kHz}$} \\
\hline 0 & 0,538 & 0,543 & - & - & - & - & & \\
\hline 24 & 1,154 & 1,159 & 0.616 & 0.652 & 0.163006 & 0.170681 & & \\
\hline 36 & 1,204 & 1,209 & 0.05 & 0.044 & 0.013058 & 0.011387 & & \\
\hline 40 & 1,201 & 1,206 & -0.003 & -0.027 & -0.00078 & -0.00704 & + & + \\
\hline 44 & 1,202 & 1,207 & 0.001 & 0.039 & 0.000261 & 0.010062 & & \\
\hline 48 & 1,217 & 1,222 & 0.015 & 0.046 & 0.003904 & 0.011847 & & \\
\hline
\end{tabular}

Table 1. Parameters determined

Figure 3 presents a picture of bean seeds, Pink variety, after a certain period of treatment. 


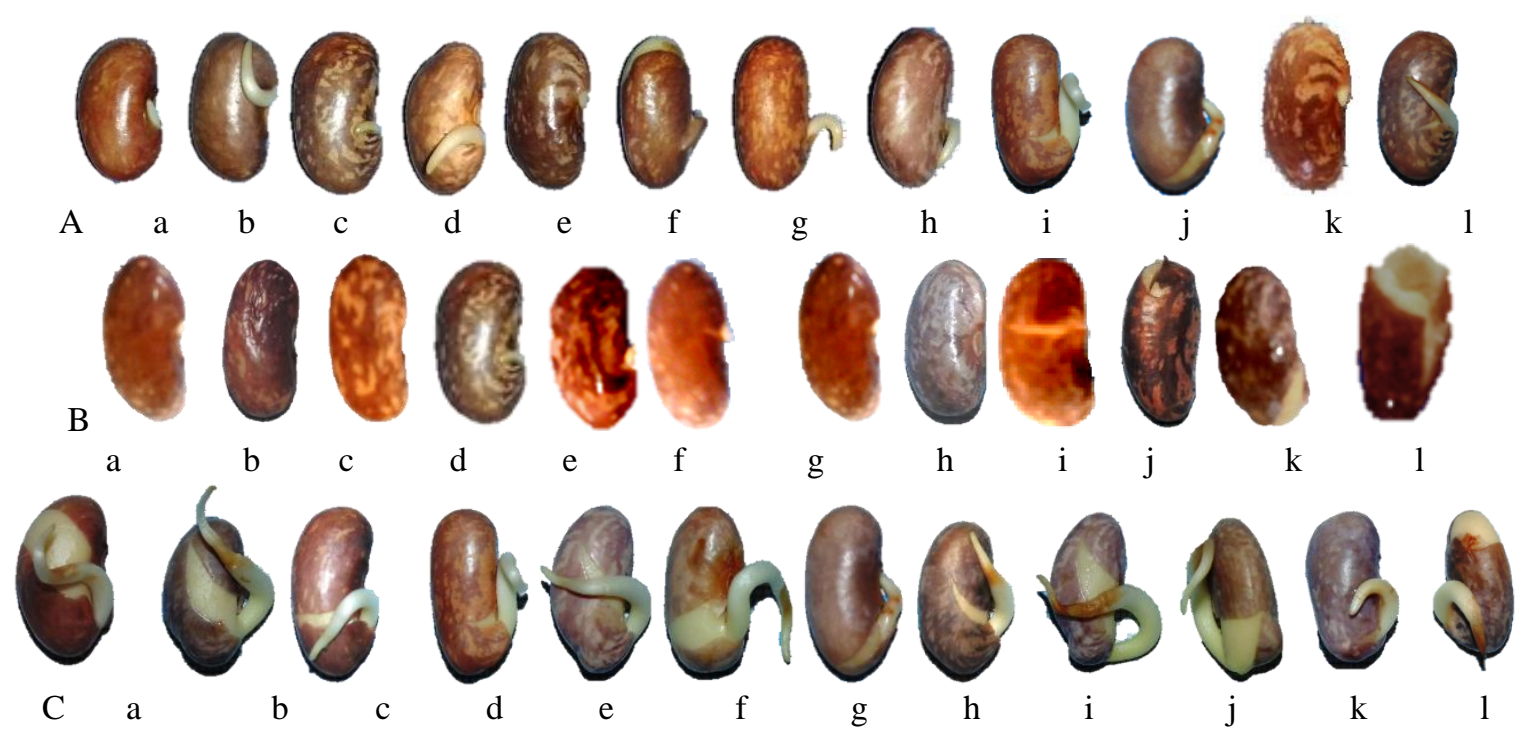

Fig. 3. The image of acoustically treated seeds:

A- after 48 hours, soaked in thermally treated water; B- after 48 hours, soaked in plain water, C- after 72 hours, soaked in thermally treated water:

a- control; b- 0,1 kHz; c- 0,5 kHz; d- 1 kHz; e -2 kHz; f- $3 \mathrm{kHz}$; g - $4 \mathrm{kHz}$; h $-5 \mathrm{kHz}$; $-6 \mathrm{kHz}$; $-7 \mathrm{kHz}$; -8

$\mathrm{kHz} ; 1-9 \mathrm{kHz}$.

It was found that the seeds treated with frequencies in the range of $3 \div 6 \mathrm{kHz}$ gained in mass the most, whatever type of water was used. Water absorption capacity is an important factor, directly related to germination speed and seedling formation. During the next 36-48 hours, sound waves with specific frequencies have shown significant effects on biological and physiological seed activities. Therefore, applying acoustic waves to the seeds leads to hastening the germination process.

In the case of soaking the seeds in plain water, not all frequency ranges have demonstrated beneficial effects on the germination process: under the same treatment conditions, the seeds from the sets treated with 6-9 $\mathrm{kHz}$ showed cracked skin and some of them did not germinate. This is explained by the negative values of the turgor pressure, which leads to the peeling of the skin cell wall and favors the triggering of putrefaction process. In this way, it has been found that frequencies in the range of 6 to $9 \mathrm{kHz}$ inhibit bean embryo development.

The negative effect of these frequency ranges is demonstrated through $\mathrm{pH}$ changes, from neutral, in the initial stage, to a basic one (8.5). Major effects of $\mathrm{pH}$ levels include gaps in the availability of nutrients and the presence of high concentrations of minerals that are harmful for the seeds and embryos.

\subsection{Influence of sound waves on the process of growth}

As in the case of the germination process, different effects were remarked depending on the frequency range used for seed treatment and the type of water used to soak the beans in. Thus, the sets of seeds soaked in heat treated water recorded the shortest time of germination, with a germination and emergence rate of $100 \%$ compared to the control groups.

Figure 4 presented the dynamic growth of bean plants according to the treatment to which the seeds were subjected, and the type of water in which they were initially soaked up to the point of germination. From the diagram, it is observed that the sample sets soaked in plain water reached maximum productivity, compared to the control group, only when treated in the $2-5 \mathrm{kHz}$ frequency range. 

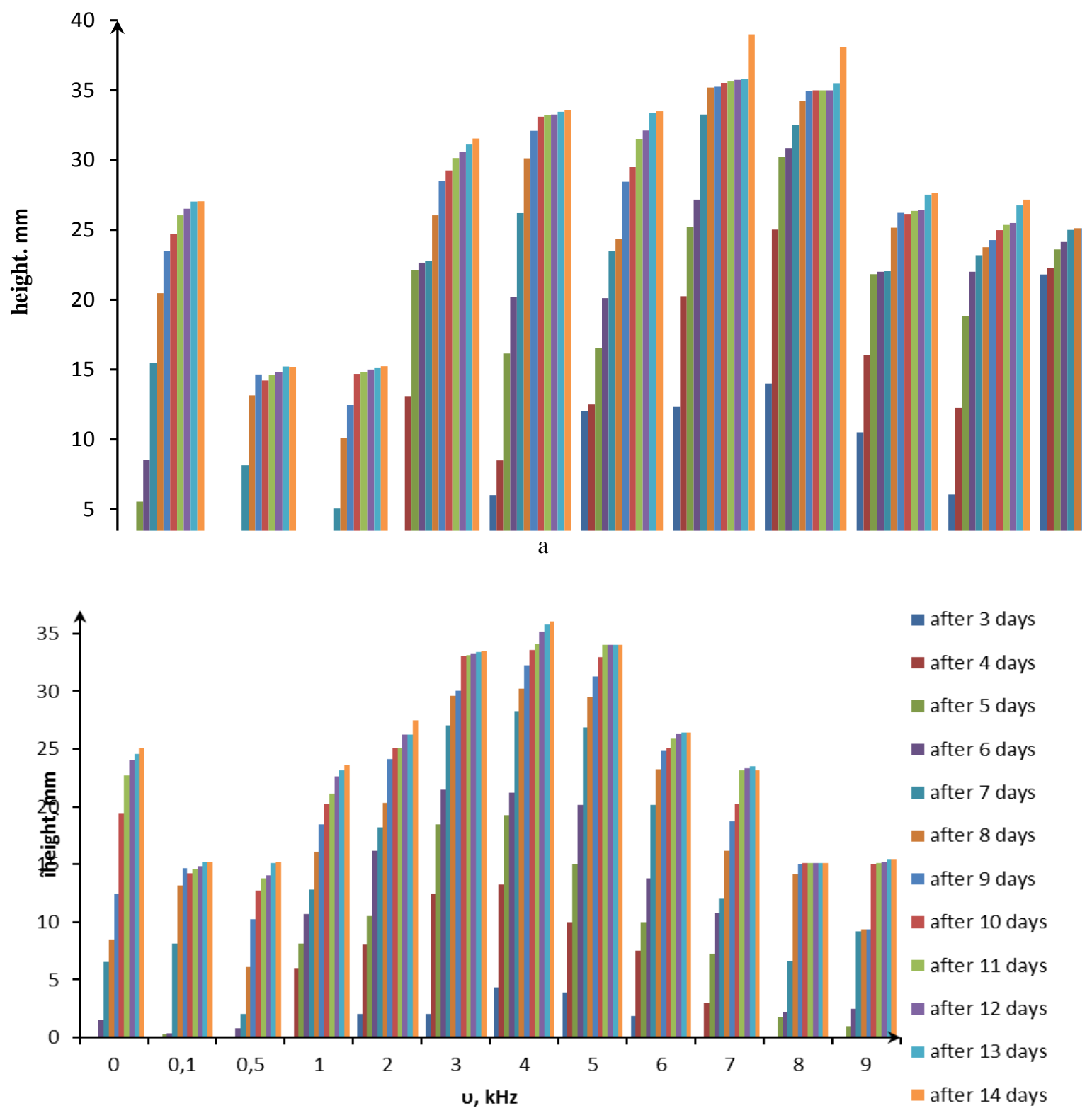

$\mathrm{b}$

Fig. 4. Dynamic growth of bean plants after germination, stimulated with: a- heat treated water, b- plain water

The sets soaked in heat-treated water showed significant results when compared with the control sample for the range of 1-7 kHz frequency. Significant results of the effects of sound waves were also observed on the increase in strain diameter (Table 2).

At the same time, it has been found that high frequency sound waves can harm adequate growth and development of the plant. Thus, the groups treated with frequencies in the range of $7-9 \mathrm{kHz}$ developed at a slower rate, the plants were feeble, some of them even died after a short period of time. 
Table 2. The diameter of bean crop strains $(\mathrm{cm})$

\begin{tabular}{|c|c|c|c|c|c|c|c|c|c|c|}
\hline & \multicolumn{2}{|c|}{0} & \multicolumn{2}{|c|}{0.5} & \multicolumn{2}{|c|}{3} & \multicolumn{2}{|c|}{4} & \multicolumn{2}{|c|}{9} \\
\hline & $\begin{array}{c}\text { Treated } \\
\text { water }\end{array}$ & $\begin{array}{l}\text { Plain } \\
\text { water }\end{array}$ & $\begin{array}{c}\text { Treated } \\
\text { water }\end{array}$ & $\begin{array}{l}\text { Plain } \\
\text { water }\end{array}$ & $\begin{array}{c}\text { Treated } \\
\text { water }\end{array}$ & $\begin{array}{l}\text { Plain } \\
\text { water }\end{array}$ & $\begin{array}{c}\text { Treated } \\
\text { water }\end{array}$ & $\begin{array}{l}\text { Plain } \\
\text { water }\end{array}$ & $\begin{array}{c}\text { Treated } \\
\text { water }\end{array}$ & $\begin{array}{l}\text { Plain } \\
\text { water }\end{array}$ \\
\hline 3 & - & - & 0,3 & - & 0,359 & 0,360 & 0,407 & 0,401 & 0,215 & - \\
\hline 4 & - & - & 0,3 & - & 0,392 & 0,399 & 0,455 & 0,425 & 0,280 & - \\
\hline 5 & 0,405 & - & 0,5 & - & 0,431 & 0,455 & 0,467 & 0,439 & 0,304 & 0,257 \\
\hline 6 & 0,426 & 0,302 & 0,5 & 0,315 & 0,472 & 0,483 & 0,484 & 0,455 & 0,316 & 0,286 \\
\hline 7 & 0,450 & 0,315 & 0,5 & 0,324 & 0,486 & 0,490 & 0,503 & 0,476 & 0,322 & 0,301 \\
\hline 8 & 0,468 & 0,347 & 0,5 & 0,356 & 0,498 & 0,492 & 0,511 & 0,499 & 0,330 & 0,308 \\
\hline 9 & 0,482 & 0,359 & 0,5 & 0,370 & 0,509 & 0,498 & 0,515 & 0,501 & 0,345 & 0,311 \\
\hline 10 & 0,500 & 0,375 & 0,5 & 0,377 & 0,513 & 0,502 & 0,519 & 0,511 & 0,345 & 0,311 \\
\hline 11 & 0,503 & 0,389 & 0,5 & 0,381 & 0,519 & 0,504 & 0,522 & 0,512 & 0,346 & 0,315 \\
\hline 12 & 0,505 & 0,392 & 0,5 & 0,383 & 0,521 & 0,507 & 0,526 & 0,514 & 0,348 & 0,316 \\
\hline 13 & 0,509 & 0,401 & 0,5 & 0,388 & 0,522 & 0,510 & 0,527 & 0,517 & 0,348 & 0,317 \\
\hline
\end{tabular}

\section{CONCLUSIONS}

The experimental results obtained show that sound frequencies, as well as the type of water used for the treatment, influence the biological and physiological activities of bean seeds. In comparison with the sample sets soaked in plain water, those immersed in treated water reached a germination and emergence rate of $100 \%$ as opposed to $60 \%$. Also, a reduction of the germination period and an increase of the productive potential of the seeds treated in the $2-6 \mathrm{kHz}$ acoustic frequency range and soaked in thermally treated water were recorded. However, sound waves with frequencies above $8 \mathrm{kHz}$ prevented the harmonious development of the cultures, during the germination and the growth stage, some of them even died. Using this method in agricultural production will allow obtaining intense and qualitative productivity with no impact on the environment.

\section{REFERENCES}

[1] Vasilevski, G., Perspectives of the application of biophysical methods in sustainable agriculture, Bulgarian Journal of plant physiology, Special issue, 2003, p.179-186.

[2] Aladjadjiyan, A., Physical Factors for Plant Growth Stimulation Improve Food Quality, Food production approaches, Challenges and tasks, 2012, p. 145-168.

[3] Lozovanu, P., Moşneaga, A., Livinţi P., Lozovanu, D., Acţiunea factorilor fizici asupra procesului de germinare şi a dinamicii creşterii culturilor agricole, Culegere de lucrări ale Conferinţei ştiinţifice integrare prin cercetare şi inovare, Chişinău, CEP USM, 2013, p.123-124.

[4] Telewski, F.W., A unified hypothesis of mechanoperception in plants, American journal of botany, vol. 93, 2006, 1466-1476.

[5] Jeong, M.J., Shim, C.K., Lee, J.O., Kwon, H.B., Kim, Y.H., Lee, S.K., Byun, M.O., Park, S.C., Plant gene responses to frequency-specific sound signals, Molecular Breeding, vol. 21, 2004, 217-226.

[6] Netsvetov, M.V., Kuzik, A.V., Hijenkov, P.K.K., Voprosu o mehanisme vlyanie nizko- i cverhnizko chastotnih mehanicheskih kolebanii na pronitsaemosti rastitelinih membrane, B.CH. 2., Donetsk, 2001, p. 14-16. 